\title{
PENGARUH PEMBERIAN ZINK TERHADAP KUALITAS SPERMATOZOA PADA MENCIT JANTAN (Mus musculus)
}

\author{
${ }^{1}$ Kory Oktapiani Payaran \\ ${ }^{2}$ Benny Wantouw \\ ${ }^{2}$ Lydia Tendean
}

\author{
${ }^{1}$ Kandidat Skripsi Fakultas Kedokteran Universitas Sam Ratulangi Manado \\ ${ }^{2}$ Bagian Biologi Fakultas Kedokteran Universitas Sam Ratulangi Manado \\ Email: payarankory@gmail.com
}

\begin{abstract}
Abstrak: Zink termasuk dalam golongan mikro mineral dalam tubuh untuk menjaga dan memperbaiki metabolisme tubuh. Zink berperan penting dalam pertumbuhan dan perkembangan, respon kekebalan,fungsi neurologis dan reproduksi. Tujuan dari penelitian ini adalah untuk mengetahui pengaruh zink serta mekanismenya terhadap kualitas spermatozoa mencit. Penelitian ini bersifat observasional deskriptif yang dilakukan pada bulan November sampai Desember 2013 dengan menggunakan sampel sebanyak 24 ekor terdiri dari 6 ekor mencit sebagai kontrol $\left(\mathrm{P}_{0}\right), 6$ mencit diberi zink dengan dosis $10 \mathrm{mg}\left(\mathrm{P}_{1}\right), 6$ mencit dengan dosis $20 \mathrm{mg}\left(\mathrm{P}_{2}\right)$ dan 6 mencit dengan dosis $30 \mathrm{mg}\left(\mathrm{P}_{3}\right)$. Hasil penelitian ini didapatkan peningkatan konsentrasi spermatozoa pada kelompok perlakuan $\mathrm{P}_{3}$ sebesar 82,25 $\times 10^{5}$, peningkatan motilitas spematozoa pada perlakuan kelompok $\mathrm{P}_{3}$ sebesar $64,05 \%$ dan morfologi normal spermatozoa pada kelompok perlakuan $\mathrm{P}_{3}$ sebesar 71, 81\%. Kesimpulan dari penelitian ini didapatkan bahwa dengan pemberian dosis zink yang dinaikkan maka akan meningkatkan kualitas spermatozoa mencit jantan yang meliputi konsentrasi, motilitas dan morfologi spermatozoa.
\end{abstract}

Kata Kunci: zink, mencit jantan, kualitas spermatozoa.

\begin{abstract}
Abstrak: Zinc belongs to micro mineral class, which is required by the body to keep and repair the body metabolism. Zinc has an importan role in growth and development, immunity, neurologic function, and reproduction. This study was carried out to find the effect of zinc on mice spermatozooa and it's mechanism. This is an observational descriptive study which was conducted from November to December 2013. There were 24 mice used in this study, which were grouped into 4 different groups, each consists of 6 mice. The first one is the control group $\left(\mathrm{P}_{0}\right)$, the second group $\left(\mathrm{P}_{1}\right)$ was given $10 \mathrm{mg}$ of zinc, the third group $\left(\mathrm{P}_{2}\right)$ was given $20 \mathrm{mg}$ of zinc, and the fourth group $\left(\mathrm{P}_{3}\right)$ was given $30 \mathrm{mg}$ of zinc. Result shows increased spermatozoa concentration in group $\mathrm{P}_{3}$, as many as $82.25 \times 10^{5}$; increased spermatozoa motility in group $\mathrm{P}_{3}$, as much as 64.05\%; and also spermatozoa's normal morphology in group $\mathrm{P}_{3}$, as much as $71.81 \%$. Based on our findings we concluded that greater zinc dosage will increase the quality of male mice's spermatozoa, includes spermatozoa's concentration, motility, and morphology.
\end{abstract}

Keyword: zinc, male mice, the quality of spermatozoa.

Gangguan transportasi sperma dan gangguan fungsi sperma sangat berpengaruh terhadap kesuburan. Gaya hidup modern juga sangat berpengaruh terhadadap masalah tersebut. Hal ini berhubungan dengan meningkatnya paparan terhadap stres oksidatif, seperti emisi gelombang radiasi, tingkat polusi yang tinggi serta jenis makanan yang makin bervariasi dan kurang sehat yang mengakibatkan gangguan pada kualitas spermatozoa. ${ }^{1}$ Penanganan untuk perbaikan kualitas sperma adalah suplemen 
zink. Zink dapat terkandung dalam makanan sehari- hari, dengan konsentrasi paling tinggi terdapat pada makanan yang mengandung protein hewani, seperti kerang, daging sapi, daging ayam dan produk daging lainnya. Bagi vegetarian, asupan zink bisa didapatkan dari kacang- kacangan, serta sayur dan buah-buahan. ${ }^{2}$

Unsur zink adalah semacam mikro mineral yang terdapat di dalam tubuh. Unsur ini sangat diperlukan untuk menjaga dan memperbaiki metabolisme dalam tubuh. ${ }^{3}$ Zink merupakan bagian dari berbagai jenis enzim dan bagian dari hormon insulin. Metabolismenya zink diangkut oleh albumin dalam plasma, disimpan dalam otot, tulang, dan organ. ${ }^{4}$ Fungsi dan peran zink dalam tubuh antara lain membantu pembuatan materi genetik sel-sel, pembentukan sel darah merah (hemoglobin),serta membantu fungsi-fungsi pankreas dalam proses pencernaan. Dari sekian banyak manfaat zink,yang tidak kalah penting adalah manfaat zink dalam sistem reproduksi. ${ }^{5}$

Zink yang merupakan konstituen dari superoksida dismutase, enzim yang melindungi sel-sel dari kerusakan yang disebabkan oleh radikal bebas. Sel sperma yang aktif secara metabolik dan menghasilkan sejumlah besar radikal bebas selama pengembanganya. Zink menghasilkan sistem enzin yang membantu menetralkan radikal bebas. Tingkat zink yang rendah dalam sperma berkorelasi dengan konsentrasi sperma lebih rendah, pergerakan sperma yang rendah dan morfologi sperma yang abnormal. $^{6}$

Berdasarkan latar belakang di atas, peneliti merasa tertarik untuk mengetahui sejauh mana pengaruh suplemen zink terhadap kualitas spermatozoa yang meliputi konsentrasi, motilitas, dan morfologi dengan menggunakan hewan uji mencit jantan (Mus musculus).

\section{METODE PENELITIAN}

Penelitian ini menggunakan metode observasional deskriptif. Penelitian ini dilakukan di Laboratorium Dasar Biologi Fakultas FMIPA Universitas Sam Ratulangi
Manado dengan rentang waktu sekitar November 2013- Januari 2014. Penelitain ini menggunakan sampel sebanyak 24 ekor mencit jantan yang dibagi menjadi 4 kelompok masing- masing kelompok terdiri dari 6 ekor mencit dan diberi perlakuan selama 32 hari dengan pemberian zink melalui sonde lambung. Kelompok pertama merupakan kelompok kontrol, kelompok kedua diberikan zink dengan dosis $10 \mathrm{mg}$, kelompok ketiga diberikan zink dengan dosis $20 \mathrm{mg}$ dan kelompok keempat diberikan zink dengan dosis $30 \mathrm{mg}$.

\section{HASIL PENELITIAN}

\section{Konsentrasi spermatozoa}

Setelah dilakukan perlakuan pemberian zink selama 32 hari dan penelitian terhadap konsentrasi spermatozoa mencit pada masing- masing kelompok maka didapatkan hasil seperti yang terlihat pada Tabel 1 .

Tabel 1. Hasil Perhitungan rata-rata konsentrasi spermatozoa mencit setelah perlakuan pemberian zink selama 32 hari.

\begin{tabular}{cc}
\hline Kelompok Sampel & $\begin{array}{c}\text { Rata-rata } \\
\text { konsentrasi } \\
\text { spermatozoa }\left(\times \mathbf{1 0}^{\mathbf{5}}\right)\end{array}$ \\
\hline Kontrol $\left(\mathrm{P}_{0}\right)$ & 76,83 \\
Perlakuan $\left(\mathrm{P}_{1}\right)$ & 78,16 \\
Perlakuan $\left(\mathrm{P}_{2}\right)$ & 79,5 \\
Perlakuan $\left(\mathrm{P}_{3}\right)$ & 82,25 \\
\hline
\end{tabular}

Keterangan: Kelompok $\mathrm{P}_{0}$, kontrol (tidak diberi perlakuan); Kelompok $\mathrm{P}_{1}$, pemberian zink $10 \mathrm{mg}$; Kelompok $\mathrm{P}_{2}$, pemberian zink $20 \mathrm{mg}$; Kelompok $\mathrm{P}_{3}$, pemberian zink $30 \mathrm{mg}$.

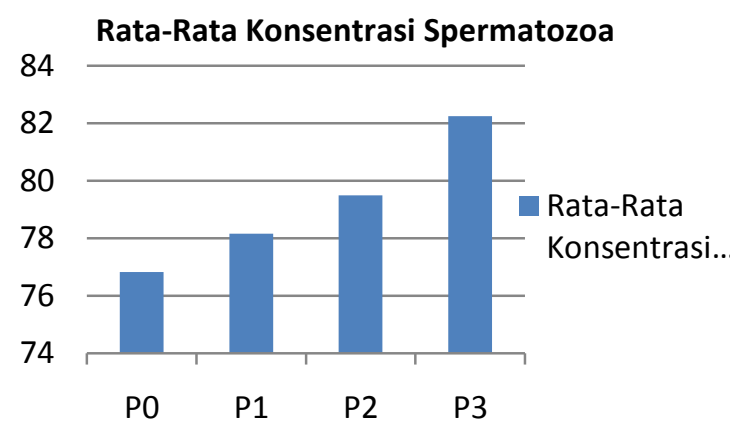

Gambar 1. Diagram Rata- Rata Konsentrasi Spermatozoa Mencit (Mus musculus) setelah Perlakuan dengan Pemberian Zink selama 32 hari. 
Berdasarkan Tabel 1 dan Gambar 1 dapat dilihat bahwa terdapat kecenderungan peningkatan rata-rata konsentrasi spermatozoa mencit setelah dilakukan perlakuan penberian zink dengan dosis yang berbeda- beda selama 32 hari. Semakin bertambah dosis zink yang diberikan, semakin terjadi peningkatan konsentrasi spermatozoa mencit.

Kelompok $\mathrm{P}_{0}$ sebagai kelompok kontrol yaitu kelompok yang tidak diberikan pemberian zink menunjukkan rata- rata konsentrasi spermatozoa sebesar 76,83 $\times 10^{5}$ sperma/ml suspensi. Kelompok $\mathrm{P}_{1}$ sebagai kelompok perlakuan dengan pemberian zink $10 \mathrm{mg}$ menunjukkan ratarata konsentrasi spermatozoa yang mengalami peningkatan yaitu 78,16 $\times 10^{5}$ sperma/ml suspensi atau lebih tinggi dari kelompok kontrol $\mathrm{P}_{0}$. Kelompok $\mathrm{P}_{2}$ sebagai kelompok perlakuan dengan pemberian dosis zink sebesar $20 \mathrm{mg}$ menunjukkan ratarata konsentrasi spermatozoa yang terus meningkat menjadi $79,5 \times 10^{5}$ sperma $/ \mathrm{ml}$ suspensi atau lebih tinggi dibandingkan dengan kelompok kontrol $\mathrm{P}_{0}$ dan kelompok perlakuan $\mathrm{P}_{1}$. Sedangkan kelompok $\mathrm{P}_{3}$ sebagai kelompok perlakuan dengan pemberian dosis zink sebesar $30 \mathrm{mg}$ menunjukkan rata- konsentrasi spermatozoa yang paling tinggi yaitu $82,25 \times 10^{5}$ sperma/ml suspensi.

\section{Motilitas Spermatozoa}

Setelah dilakukan pemberian zink selama 32 hari dan penilaian terhadap motilitas spermatozoa mencit pada masingmasing kelompok maka hasil yang didapatkan terbagi menjadi 4 kelas, yaitu kelas A sperma yang bergerak maju dengan cepat, kelas B sperma yang belok, kelas C sperma yang bergerak di tempat, dan kelas D sperma yang diam atau tidak bergerak.

\section{Motilitas Spermatozoa}

Motilitas spermatozoa adalah gerakan spermatozoa yang maju lurus dan cepat (progresif).
Tabel 2. Hasil Perhitungan Rata- Rata Motilitas Spermatozoa Mencit Kelas A setelah Perlakuan Pemberian Zink selama 32 hari.

\begin{tabular}{cc}
\hline Kelompok Sampel & $\begin{array}{c}\text { Rata- Rata Motilitas } \\
\text { Spermatozoa Kelas A } \\
(\mathbf{1 0 0 \% )}\end{array}$ \\
\hline Kontrol $\left(\mathrm{P}_{0}\right)$ & 54,64 \\
Perlakuan $\left(\mathrm{P}_{1}\right)$ & 58,08 \\
Perlakuan $\left(\mathrm{P}_{2}\right)$ & 61,44 \\
Perlakuan $\left(\mathrm{P}_{3}\right)$ & 64,05 \\
\hline
\end{tabular}

Ket: Kelompok $\mathrm{P}_{0}$, kontrol (tidak diberi perlakuan); Kelompok $\mathrm{P}_{1}$, pemberian zink $10 \mathrm{mg}$; Kelompok $\mathrm{P}_{2}$, pemberian zink $20 \mathrm{mg}$; Kelompok $\mathrm{P}_{3}$, pemberian zink $30 \mathrm{mg}$.



Gambar 2. Diagram Rata- Rata Motilitas Spermatozoa Mencit Kelas A ( Mus musculus) setelah Perlakuan dengan Pemberian Zink selama 32 hari.

Dari Tabel 2 dan Gambar 2 dapat dilihat bahwa terdapat kecenderungan peningkatan rata- rata persentase motilitas spermatozoa mencit kelas A setelah dilakukan perlakuan pemberian zink selama 32 hari. Semakin besar dosis yang diberikan, semakin terjadi peningkatan rata- rata persentase motilitas spermatozoa mencit kelas A.

Kelompok $\mathrm{P}_{0}$ sebagai kelompok kontrol yaitu kelompok yang tidak diberikan zink menunjukkan rata- rata persentase motilitas spermatozoa sebesar 54,64 \%. Kelompok $\mathrm{P}_{1}$ yaitu kelompok perlakuan dengan pemberian dosis zink $10 \mathrm{mg}$ menunjukkan ratarata presentase motilitas spermatozoa yang meningkat menjadi 58,08 \% atau lebih 
tinggi dibandingkan dengan kelompok kontrol $\mathrm{P}_{0}$. Kelompok perlakuan $\mathrm{P}_{2}$ dengan peberian dosis zink 20 mg menunjukkan rata- rata presentase motilitas spermatozoa yang terus mengalami peningkatan menjadi $61,44 \%$ atau lebih tinggi dibandingkan dengan kelompok kontrol $\mathrm{P}_{0}$ dan kelompok perlakuan $\mathrm{P}_{1}$. Sedangkan kelompok $\mathrm{P}_{3}$ sebagai kelompok perlakuan yang diberikan dosis zink sebesar $30 \mathrm{mg}$ menunjukkan ratarata presentase motilitas spermatozoa mencit yang paling tinggi yaitu 64,05 \%.

\section{Morfologi Spermatozoa}

Setelah dilakukan perlakuan pemberian zink selama 32 hari dan penelitian terhadap morfologi spermatozoa mencit maka hasil yang didapatkan terbagi menjadi dua, yaitu morfologi normal dan abnormal spermatozoa mencit.

\section{Morfologi Normal Spermatozoa}

Tabel 3. Hasil analisa rata-rata morfologi normal spermatozoa mencit setelah perlakuan pemberian zink selama 32 hari.

\begin{tabular}{cc}
\hline Kelompok Sampel & $\begin{array}{c}\text { Rata- Rata Morfologi } \\
\text { Normal Spermatozoa } \\
(\mathbf{1 0 0 \% )}\end{array}$ \\
\hline Kontrol $\left(\mathrm{P}_{0}\right)$ & 56,32 \\
Perlakuan $\left(\mathrm{P}_{1}\right)$ & 59,09 \\
Perlakuan $\left(\mathrm{P}_{2}\right)$ & 64,78 \\
Perlakuan $\left(\mathrm{P}_{3}\right)$ & 71,81 \\
\hline
\end{tabular}

Keterangan: Kelompok $\mathrm{P}_{0}$, kontrol (tidak diberi perlakuan); Kelompok $\mathrm{P}_{1}$, pemberian zink $10 \mathrm{mg}$; Kelompok $\mathrm{P}_{2}$, pemberian zink $20 \mathrm{mg}$; Kelompok $\mathrm{P}_{3}$, pemberian zink $30 \mathrm{mg}$.

Rata- Rata Morfologi Normal Spermatozoa

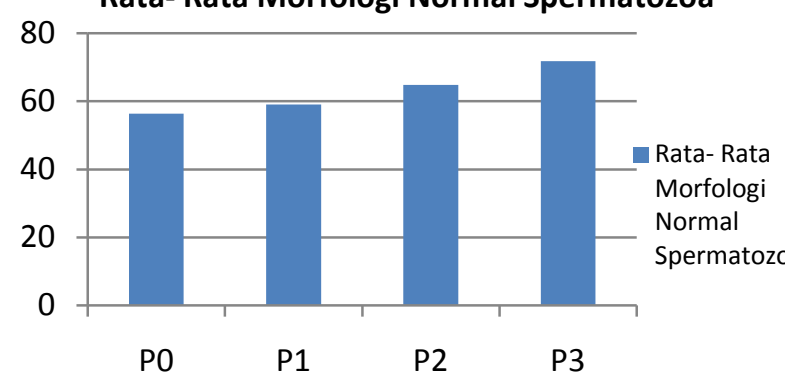

Gambar 3. Diagram Rata- Rata Morfologi Normal Spermatozoa Mencit (Mus musculus) setelah Perlakuan dengan Pemberian Zink selama 32 hari.
Dari Tabel 3 dan Gambar 3 menunjukkan bahwa terdapat kecenderungan peningkatan morfologi normal spermatozoa mencit setelah perlakuan pemberian zink selama 32 hari. Semakin bertambah jumlah dosis zink yang diberikan,semakin terjadi peningkatan morfologi normal spermatozoa mencit.

Kelompok $\mathrm{P}_{0}$ sebagai kelompok kontrol yang tidak diberikan perlakuan menunjuk-kan rata-rata presentase morfologi normal spermatozoa sebesar $56,32 \%$. Kelompok perlakuan $\mathrm{P}_{1}$ dengan pemberian zink $10 \mathrm{mg}$ menunjukkan ratarata presentase morfologi spermatozoa mengalami peningkatan men-jadi 59,09 \% atau lebih tinggi dibandingkan kelompok kontrol $\mathrm{P}_{0}$. Kelompok $\mathrm{P}_{2}$ merupa-kan kelompok perlakuan dengan pemberian zink $20 \mathrm{mg}$ terus meningkat menjadi 64,78\% atau lebih tinggi dibandingkan kelompok kontrol $\mathrm{P}_{0}$ dan kelompok perlakuan $\mathrm{P}_{1}$. Sedangkan kelompok perlakuan $\mathrm{P}_{3}$ dengan pemberian zink $30 \mathrm{mg}$ menunjukkan ratarata presentase yang paling tinggi yaitu 71 , $81 \%$.

\section{BAHASAN}

\section{Konsentrasi spermatozoa}

Pada penelitian ini didapatkan hasil analisis yang menunjukkan bahwa semakin banyak dosis zink yang diberikan maka konsentrasi spermatozoa semakin meningkat. Hal itu disebabkan karena peranan zink yang berhubungan dengan stimulasi hormon androge (testosteron) pada sel Leyding. Apabila mineral zink dalam darah meningkat maka stimulasi hormon testosteron akan meningkat sehingga aktifitas seksual terutama pembentukan spermatozoa akan meningkat. ${ }^{7}$ Selain itu mineral zink juga berperan sebagai antioksidan yang melindungi tubuh dari serangan lipid peroksidase. ${ }^{8}$

\section{Motilitas spermatozoa}

Pada penelitaian ini didapatkan hasil yang menunjukkan bahwa semakin banyak dosis zink yang diberikan maka motilitas spermatozoa meningkat karena fungsi dari mineral zink terhadap kerja enzim metabolisme sel sperma yang menyediakan ATP 
sebagai energi gerak bagi spermatozoa sehingga spermatozoa lebih aktif. ${ }^{7}$

\section{Morfologi spermatozoa}

Pada penelitian ini peningkatan morfologi normal spermatozoa diakibatkan karena peranan zink yang dapat menstimulasi hormon androgen sehingga dapat meningkatkan proses spermatogenesis yang normal dan pematangan spermatozoa. ${ }^{8}$

\section{SIMPULAN}

1. Pemberian zink menyebabkan peningkatan kualitas spermatozoa secara nyata yang meliputi konsentrasi spermatozoa, motilitas spermatozoa, dan morfologi spermatozoa normal.

2. Semakin besar dosis zink yang diberikan semakin besar efek peningkatan kualitas spermatozoa.

3. Zink dapat meningkatkan kualitas spermatozoa karena fungsi dan peranan zink dalam sistem reproduksi yaitu zink berfungsi sebagai antioksidan dan menstimulasi hormon androgen (testosteron) pada sel Leyding sehingga dapat meningkatkan proses spermatogenesis yang normal.

\section{DAFTAR PUSTAKA}

1. Andon H. Infertilitas. Dalam: Mochamad A, Ali B, Prajitno P, editor. Ilmu kandungan.
Edisi ketiga, Jakarta: PT Bina Pustaka Sarwono Prawirohardjo; 2011.hlm 424.

2. Qauratul AS. Efektifitas suplemen zink yang beredar di Indonesia terhadap jumlah dan motilitas sperma mencit galur swiss webster [skripsi]. 2011. Hlm.1.

3. Trevino AP, Elvina K, Ni Made DS, Michael S,Nining D,Hans B, et all. Zinc and vitamin A Supplementation Fails to Reduce Sputum Conversion Time in Severely Malnourished Pulmonary Tuberculosis Patient in Indonesia. Nutrition Journal. 2010.Diunduh dari: www.nutritionj.com/content/9/1/41. Diakses tanggal 15 September 2013

4. Soetarjo S, Soekatri M, Almatsier S, editor. Gizi seimbang dalam daur kehidupan. Jakarta: PT Gramedia Pustaka Utama. 2011.hlm.26.

5. Nicola ML, Katalin F, Tamas D. Methods of Assesment of Zink Status in Humans: a systematic review. Am J Clin Nutr.2009. Diunduh dari: http://ajcn.nutrition.org/content/suppl/2009/0 5/20/ajcn.2009.27230G.DC1.html. Diakses tanggal 15 September 2013.

6. Titan Harlisty. Defisiensi Zinc Menyebabkan Gangguan Kualitas Sperma. [skrpsi] 2012. Hlm.2.

7. Suharyati S. Pengaruh Penambahan Vitamin E dan Mineral Zn Terhadap Kualitas Semen Serta Fertilitas Dan Daya Tetas Telur Kalkun Lokal. J.Indon. Trop. Anim.Agric; September 2006.

8. Suharyati S, Hartono M. Peningkatan Kualitas Semen Kambing Boer Dengan Pemberian Vitamin E Dan Mineral Zn. Jurnal Kedokteran Hewan; September 2013, Vol.7. 